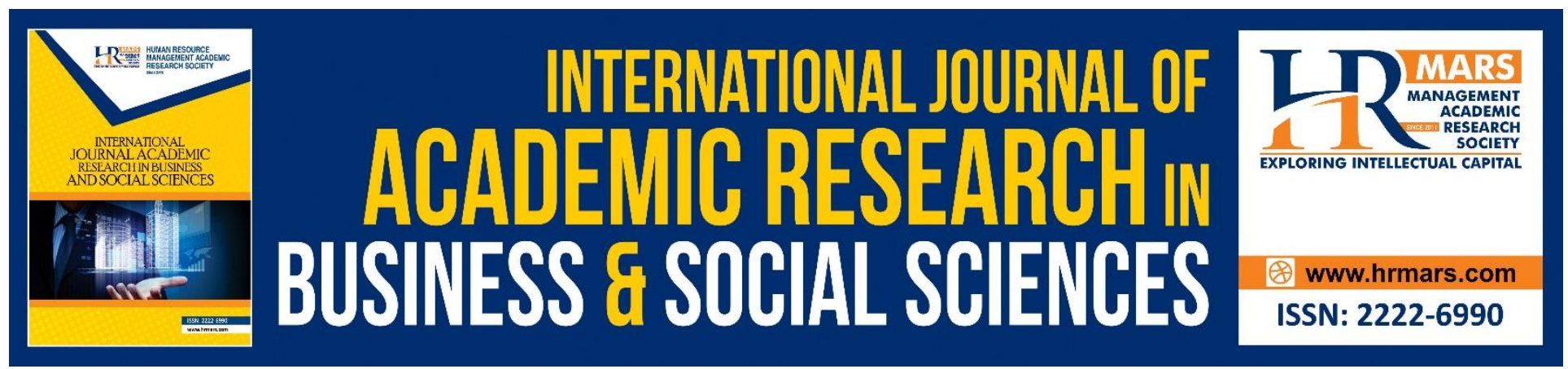

\title{
Love and Marital Satisfaction Among Malaysian Ethnic Chinese
}

\author{
Teoh Wan Yee, Suzana Mohd Hoesni, Nor Ba'yah Abdul Kadir, Dan Zainah \\ Ahmad Zamani
}

To Link this Article: http://dx.doi.org/10.6007/IJARBSS/v10-i10/7939

DOI:10.6007/IJARBSS/v10-i10/7939

Received: 18 July 2020, Revised: 11 August 2020, Accepted: 15 September 2020

Published Online: 02 October 2020

In-Text Citation: (Yee, Hoesni, Abdul Kadir, \& Zamani, 2020)

To Cite this Article: Yee, T. W., Hoesni, S. M., Abdul Kadir, N. B., Zamani, D. Z. A. (2020). Love and Marital Satisfaction Among Malaysian Ethnic Chinese. International Journal of Academic Research in Business and Social Sciences. 10(10), 260-273.

Copyright: (C) 2020 The Author(s)

Published by Human Resource Management Academic Research Society (www.hrmars.com)

This article is published under the Creative Commons Attribution (CC BY 4.0) license. Anyone may reproduce, distribute, translate and create derivative works of this article (for both commercial and non-commercial purposes), subject to full attribution to the original publication and authors. The full terms of this license may be seen

at: http://creativecommons.org/licences/by/4.0/legalcode

\section{Vol. 10, No. 10, 2020, Pg. 260 - 273}

Full Terms \& Conditions of access and use can be found at http://hrmars.com/index.php/pages/detail/publication-ethics 


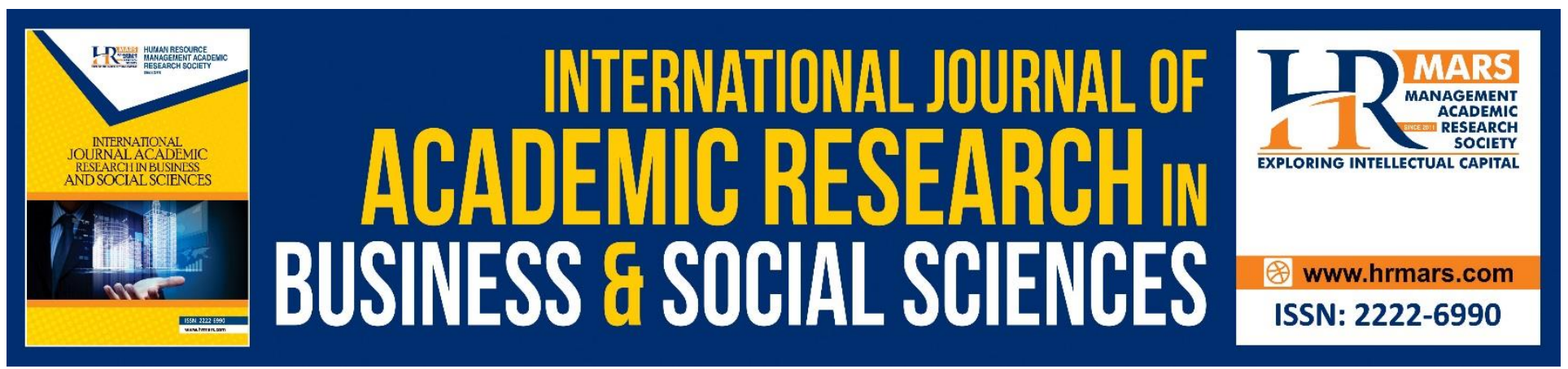

\title{
Love and Marital Satisfaction Among Malaysian Ethnic Chinese
}

\author{
Teoh Wan Yee, Suzana Mohd Hoesni, Nor Ba'yah Abdul Kadir, dan \\ Zainah Ahmad Zamani \\ Psychology and Human Well Being Research Centre, Faculty of Social Sciences and Humanities \\ National University of Malaysia \\ Email: huanyi19@gmail.com,smh@ukm.my, aknbayah@ukm.edu.my,zainah@ukm.edu.my
}

\begin{abstract}
Love is a big and subjective topic in human life. It is an important element in a marital relationship. This study aims to investigate the relationship between love and marital satisfaction among ethnic Chinese in Malaysia. This study implements a survey study design using a questionnaire aimed at gathering personal background information and measuring marital love and satisfaction among the sample population. A total of 384 ethnic Chinese samples who were Malaysian citizens in the age group from 25 years to 44 years old and have been married for at least one year and above voluntarily participated in this study. Overall, the findings showed that love has a significant relationship with marital satisfaction. Love in this study which has been divided into three components namely, intimacy $\left(r=0.852^{* *}, p<0.00\right)$, passion $\left(r=0.835^{* *}, p<0.01\right)$ and commitment $\left(r=0.737^{* *}, p\right.$ $<0.01$ ) showed a very high significant relationship with marital satisfaction. These findings show the importance of love in helping to increase marital satisfaction among married couples. Among the implications of the study is to enrich the field of psychology that focuses on marriage and culture and counselling as well as sharing knowledge that can serve as a reference to the helping profession.
\end{abstract}

Keywords: Love, Intimacy, Passion, Commitment, Marital Satisfaction.

\section{Introduction}

Marriage is a major factor in the development of human life. The intimacy of the husband and wife in a marriage is very important because the well-being of a matrimony is built based on strengthening the relationship between the husband and wife at the early stage of a love relationship (Willi, 1997; Wilfried, 2010). A harmonious relationship between husband and wife can increase marital satisfaction that act as a very inspiring social support for the individual.

Marital satisfaction is related to one's subjective well-being and means that those who have high marital satisfaction will show a higher level of subjective well-being. However, marital satisfaction has fluctuations that can be influenced by various factors (See \& Ismail, 2018). Recently, various studies have been conducted to explore marital satisfaction in various backgrounds and cultural perspectives. Thus, this situation shows that the study of marriage and marital satisfaction is 
INTERNATIONAL JOURNAL OF ACADEMIC RESEARCH IN BUSINESS AND SOCIAL SCIENCES Vol. 10, No. 10, 2020, E-ISSN: 2222-6990 @ 2020 HRMARS

necessary by looking at the well-being of marital relationships in local contexts (Razidah, 2010; Normahwati, 2012; Hidayati, 2013; Bahareh, 2014; Zakaria et al., 2018).

\section{Background of the Study}

According to Bahareh Zare (2014), the feeling of love comes from a man and a woman who are attracted to one and another due to a mysterious power that originates from instinct, tradition and submission to their own choices. This process will grow and build a dynamic institution known as the "family". Love in terms of supportive perception will create positive interactions that can contribute to marital satisfaction and avoid various problems such as instability and disagreement especially in terms of a divorce.

The context of love is considered an important factor in achieving marital satisfaction in the process of the relationship between spouses (Sprecher \& Hatfield, 2017). This situation can observe how couples or husbands and wives respond to the expectations and responsibilities set by the culture and social environment in marriage. In Western culture, marital satisfaction is closely related to the goal of self-satisfaction or ideal happiness between spouses (See \& Ismail, 2018). Even in the ethnic Chinese tradition, Confucian cultural thinking still influences the ethics of ethnic Chinese marriage (Hong \& Liu, 2013).

\section{Love}

Love is a big and subjective topic in human life. This is an important element in a marital relationship. Understanding and appreciating the definition of love is very important in overcoming various problems of moral decay caused by misunderstandings of the concept of love. Robert Sternberg $(1986,1988)$ seeks to explain love in the context of two-person relationships through the concept of "Triangular theory of love". Figure 1 below summarises the "Triangular theory of love".

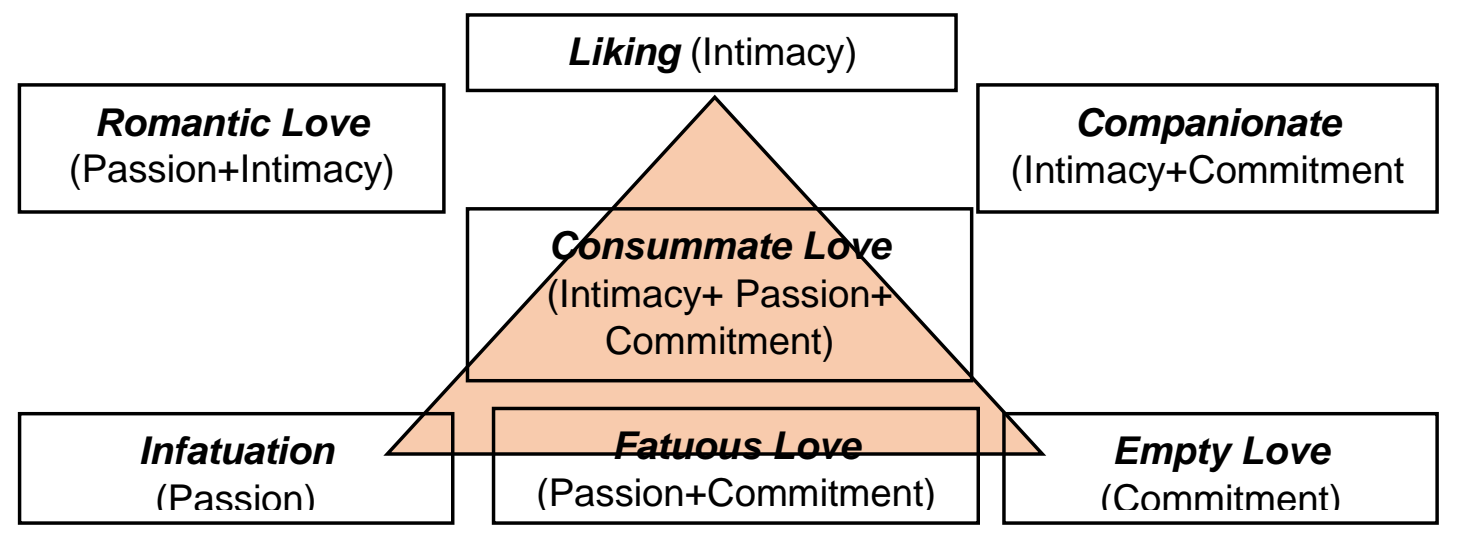

Figure 1. The Triangular Theory of Love

According to Robert Sternberg (1986), "Triangular love" contains three components: (1) intimacy, (2) passion and (3) commitment. Intimacy is an emotional element, in which there are warmth, trust and the desire to build relationships. It is characterised by the need for an individual to be close to someone, feeling happy to talk to him or her for a long time, longing when being away from each other for a long time, and the desire to hold hands or hug each other. Passion, on the other hand, is a motivational element based on sexual urges from within. For example, sincere love and the desire 
to stay close together all the time. Most of the conditions in this component are indicated by sexual behaviour. In terms of cognitive elements, commitment is the decision to continuously and consistently live life together. For example, this commitment can be in the form of vow given by a husband to his wife (Sternberg \& Weis, 2006).

He also stated that the three levels of love are often continuously going up and down. "Triangular love" can be used to describe all types of love (Wade \& Chai, p247, 2015). The patterns of these three components can form various types of relationships such as nonlover, liking or friendship, infatuation, empty love, romantic love, companionate love, fatuous love and consummate love (Papalia, Olds \& Feldman, 1998; 2009).

\section{Love and Marital Satisfaction}

Love can increase marital satisfaction because it is an element that can improve the well-being and positive psychology of a person. Previous studies have shown that love is an attitude displayed from an individual's thoughts, feelings and responses towards a partner (Gana et al., 2013). Marital satisfaction can be enhanced through the presence of love by creating cooperation and understanding between two individuals. Love also serves as a source of support and encouragement of an individual towards his or her partner by influencing the quality of marriage (Duvall \& Miller, 1985). Many factors determine the level of satisfaction and harmony in a marriage bond (Gill et al., 1999; Markman et al., 2010). One of them is the factor of love and it is an important dimension in a marriage (Hoesni et al., 2012).

According to Muchtar (2004) a significant relationship between love in the components of intimacy, passion and commitment to marital satisfaction, the components of intimacy and passion give a significant influence on marital satisfaction compared to commitment. Hally Weliangan (2016) suggests that the higher the quality of love, the higher the marital satisfaction. In fact, marital satisfaction is greatly influenced by the intimacy component. This component can contribute to marital satisfaction. The feelings of love that exist between couples can have a good effect in terms of the quality of relationships in marriage (Willi, 1997). This is because the presence of love in the relationship between the couple can reduce the probability of cheating and divorce. Thus, the style of romance plays a role in ensuring marital satisfaction (See \& Ismail, 2018).

\section{Problem Statement}

Divorced family is a new type of family structure in the present era. The phenomenon of divorce is considered a common occurrence these days. This condition is also known as the collapse of the family structure and it is frequently studied in various fields such as law, sociology, psychology, family, anthropology and sociology (Azahari, 2007; Sahlan, 2012; Imron, 2016). When the love relationship between a couple does not exist, even though the husband and wife still keep the marriage intact, the family system has faced great challenges and burdens. Its effects can affect future generations by influencing their development in terms of physical, mental and spiritual well-being (Wallerstein \& Lewis, 2004; Bert Hellinger, 2014; Ministry of Health, 2016). This condition occurs when family and parents become dysfunctional.

Divorce cases are on the rise. Statistics show that there is an increase in divorce registration every year and the number continue to increase by 33842 in 2014 and some of them only managed to keep their marriage for less than 5 years (Hameed, 2016). This situation happens since marriage is no 
INTERNATIONAL JOURNAL OF ACADEMIC RESEARCH IN BUSINESS AND SOCIAL SCIENCES Vol. 10, No. 10, 2020, E-ISSN: 2222-6990 @ 2020 HRMARS

longer considered a permanent institution. Divorce has become a terminus in love ties besides legal and formal marital relationships and an end to living as couples or a way to solve problems in families (Sahlan, 2012; Imron, 2016). In addition, it is predicted that by 2020, a total of 15 couples will get divorced in every hour, making the rate of divorce in Malaysia at 360 couples per day. This trend is very worrying for Malaysians (See \& Ismail, 2018).

Divorce cases involving Muslim couples in Selangor are the highest in the country (Kosmo, 2019). Based on the existing statistics, the number of divorce cases in each district in Selangor is increasing rapidly, although divorce case data from the Malaysian Islamic Development Department (JAKIM) and the National Registration Department (JPN) by ethnicity is not open to the public, it can even suggest that the high occurrence of divorce cases phenomenon serves as an "alarm" to warn us about the impending state of marital breakdown. Many factors are leading to divorce. Although many studies have been done related to marital satisfaction, studies focusing on the relationship between love with marital satisfaction is still new in Malaysia. Therefore, this study attempts to answer the question of whether love has anything to do with marital satisfaction among ethnic Chinese in Selangor.

\section{Methodology}

\section{Sample and Procedure}

This study was conducted in the state of Selangor. The selection of the location was made based on the fact that it met all the demands, needs and requirements of the study. The selection of sample population in the study was based on 4 criteria, namely: (1) Malaysian citizens, (2) ethnic Chinese, (3) belong to an age group of between 25 to 44 years old, and (4) have been married for at least a year. Referring to the 1970-2010 report based on the mid-year population estimate in the Malaysian Population and Housing Census data, the data for the state and population strata by state stated that Selangor is the most heavily populated state in Malaysia. The state of Selangor is one of the states that has a high concentration of ethnic Chinese (Malaysian Chinese Demographics, 2015). This is in line with the sampling criteria that is to determine the relationship between love and marital satisfaction among ethnic Chinese in Selangor. Samples were selected by purposeful sampling method. The total sample of the study is based from the sample size determination table introduced by Kerjcie \& Morgan (1970) where the calculation made for the sample is $n=384(N=1,000,000)$.

\section{Measurement}

The Triangular Love Scale developed by Sternberg (1986) has been used as a measurement tool to test the feelings and experiences the samples have towards their spouses in a love relationship. The Malay version of the measurement tool has been translated from the Subjective Meanings of Marital Love (SMML) questionnaire (Hoesni et al., 2016). The Cronbach's Alpha value of this scale has been recorded at 0.98 and has 45 question items measuring 3 subscales namely Intimation (15 items), Passion (15 items) and Commitment (15 items). The marital satisfaction using the Kansas Marital Satisfaction Scale (KMS) by Schumm, Nichols, Schectman, \& Grigsby (1986) originally had 3 items that were modified by Ismail (2005). This scale has a Cronbach's Alpha value of .93 and has 3 question items to measure marital satisfaction among the sample population.

Analytically, both descriptive and inferential statistical methods are used. According to Bowen (1978), the complete family information collection structure guided by the specific characteristics of the sample's background is very important. The demographic factors of the sample are explained with 
INTERNATIONAL JOURNAL OF ACADEMIC RESEARCH IN BUSINESS AND SOCIAL SCIENCES Vol. 10, No. 10, 2020, E-ISSN: 2222-6990 @ 2020 HRMARS

descriptive statistics that include information such as gender, age, family hierarchy, level of education, occupation, parents' marital status, length of marriage and the number of children. Pearson correlation test is used to identify the relationship between love and marital satisfaction.

\section{Findings of the Study}

Descriptive study data show the distribution of married samples by gender. The findings of the study show that the majority of 78.9 per cent (303) are women, and the number is higher than men which make up 21.1 per cent (81). Next, we examine the distribution of married samples by age. The findings show that the majority of 44.8 per cent (172) consists of those who are between 40 to 44 years old, while 32.6 per cent (125) are those between 35 to 39 years old, 13.3 per cent (51) are those between 30 to 34 years old, and the least of them, at 9.4 per cent (36) are those between 25 to 29 years old.

Regarding the distribution of married samples according to family hierarchy, the findings show that the majority of them or 42.7 per cent (164) are neither the eldest nor the youngest, compared to the firstborns who made up 34.6 per cent (133), while 22.7 per cent (8) is the youngest. Concerning the distribution of married samples according to their level of education, the findings show that the majority of them or 54.2 per cent (208) bachelor's degrees, while 19.8 per cent (76) have diplomas, 9.4 per cent (36) have master's degrees, 8.1 per cent (31) possess SPM, 5.2 per cent (20) are STPM holders, 1.8 per cent (7) have SRP / PMR, 0.8 per cent (3) completed primary school and the same percentage that is 0.8 per cent ( 3 ) have $\mathrm{PhD}$.

In terms of occupation, the findings show that the majority of the samples or 89.3 per cent (343) are working couples, while 10.7 per cent (41) of them are unemployed. Next, in regards to parents' marital status, the findings of the study showed that the highest majority or 65.1 per cent (250) of the samples have parents who are married and living together, while 24.0 per cent (92) have a deceased parent, 5.2 per cent (20) stated other reasons, 3.4 per cent (13) have parents who are married but living separately and finally, 2.3 per cent (9) have parents who are divorced.

Regarding the length of marriage, the findings show that the highest majority 31.0 per cent (119) of the samples have been married between 6 to 10 years, while 27.1 per cent (104) have been married between 11 to 15 years, 25.5 per cent (98) have been married between 1 to 5 years, 8.3 per cent (32) have been married between 21 to 25 years, and a small percentage of 8.1 per cent (31) have been married between 16 to 20 years.

Lastly, in terms of the number of children, the findings show that the majority of the sample, that is 57.3 per cent (220), comprised couples with 1 to 2 children, while 22.1 per cent (85) are couples with 3 to 4 children, 19.5 per cent (75) are couples without any children and the least, that is 1.0 per cent (4) are couples who have more than 5 children. The distribution of sample descriptive data sorted by gender, age, family hierarchy, level of education, occupation, parents' marital status, length of marriage and the number of children is explained in Table 1 below: 
INTERNATIONAL JOURNAL OF ACADEMIC RESEARCH IN BUSINESS AND SOCIAL SCIENCES Vol. 10, No. 10, 2020, E-ISSN: 2222-6990 @ 2020 HRMARS

Table 1. Descriptive Findings for Samples' Demographic Traits

\begin{tabular}{|c|c|c|}
\hline Item & Frequency & Percentage \\
\hline \multicolumn{3}{|l|}{ Gender } \\
\hline Male & 81 & 21.1 \\
\hline Female & 303 & 78.9 \\
\hline \multicolumn{3}{|l|}{ Age } \\
\hline $25-29$ years old & 36 & 9.4 \\
\hline $30-34$ years old & 51 & 13.3 \\
\hline $35-39$ years old & 125 & 32.6 \\
\hline $40-44$ years old & 172 & 44.8 \\
\hline \multicolumn{3}{|l|}{ Family Hierarchy } \\
\hline Firstborns & 133 & 34.6 \\
\hline In-between & 164 & 42.7 \\
\hline Youngest & 87 & 22.7 \\
\hline \multicolumn{3}{|l|}{ Level of Education } \\
\hline Primary School & 3 & .8 \\
\hline SRP/PMR & 7 & 1.8 \\
\hline SPM & 31 & 8.1 \\
\hline STPM & 20 & 5.2 \\
\hline Diploma & 76 & 19.8 \\
\hline Bachelor's degree & 208 & 54.2 \\
\hline Master's degree & 36 & 9.4 \\
\hline PhD & 3 & .8 \\
\hline \multicolumn{3}{|l|}{ Employment } \\
\hline Yes & 343 & 89.3 \\
\hline No & 41 & 10.7 \\
\hline \multicolumn{3}{|l|}{ Marital Status } \\
\hline Married and living together & 250 & 65.1 \\
\hline Married but living separately & 13 & 3.4 \\
\hline Divorced & 9 & 2.3 \\
\hline One of the parents is deceased & 92 & 24.0 \\
\hline Others & 20 & 5.2 \\
\hline \multicolumn{3}{|l|}{ Length of marriage } \\
\hline $1-5$ years & 98 & 25.5 \\
\hline $6-10$ years & 119 & 31.0 \\
\hline $11-15$ years & 104 & 27.1 \\
\hline $16-20$ years & 31 & 8.1 \\
\hline $21-25$ years & 32 & 8.3 \\
\hline \multicolumn{3}{|l|}{ Number of Children } \\
\hline 0 & 75 & 19.5 \\
\hline $1-2$ & 220 & 57.3 \\
\hline $3-4$ & 85 & 22.1 \\
\hline 5 and more & 4 & 1.0 \\
\hline
\end{tabular}


INTERNATIONAL JOURNAL OF ACADEMIC RESEARCH IN BUSINESS AND SOCIAL SCIENCES Vol. 10, No. 10, 2020, E-ISSN: 2222-6990 @ 2020 HRMARS

Table 2 below shows the significant relationship between intimacy and marital satisfaction. The findings show that there is a relationship between intimacy and marital satisfaction, $r=.852, p<.000$, the level of relationship is very high. Due to the positive relationship, it can be interpreted that the closer the intimacy, the higher the marital satisfaction.

Table 2. The Relationship Between Intimacy and Marital Satisfaction

\begin{tabular}{llr}
\hline Component & & Marital \\
& & Satisfaction \\
\hline \multirow{3}{*}{ Intimacy } & Pearson & $.852^{* *}$ \\
& Correlation & \\
& Sig. (2-tailed) & .000 \\
& $\mathrm{~N}$ & 384 \\
\hline
\end{tabular}

Similarly, the findings of the study (Table 3) show that there is a significant relationship between passion and marital satisfaction, $r=.835, p<.000$, the level of relationship is very high. Since the relationship is a positive one, it can be interpreted that the higher the passion, the higher the marital satisfaction.

Table 3. The Relationship between Passion and Marital Satisfaction

\begin{tabular}{llr}
\hline Component & & Marital \\
& & Satisfaction \\
\hline \multirow{3}{*}{ Passion } & Pearson & $.835^{* *}$ \\
& Correlation & \\
& Sig. (2-tailed) & .000 \\
& $\mathrm{~N}$ & 384 \\
\hline
\end{tabular}

The findings of the study as in Table 4 show that there is a significant relationship between commitment and marital satisfaction, $r=.737, p<.000$, the level of relationship is very high. Since the relationship is a positive one, then it can be interpreted that the higher the commitment, the higher the marital satisfaction.

Table 4. The Relationship Between Commitment and Marital Satisfaction

\begin{tabular}{llr}
\hline Component & & Marital \\
& & Satisfaction \\
\hline \multirow{3}{*}{ Commitment } & Pearson & $.737^{* *}$ \\
& Correlation & \\
& Sig. (2-tailed) & .000 \\
& $\mathrm{~N}$ & 384 \\
\hline
\end{tabular}


INTERNATIONAL JOURNAL OF ACADEMIC RESEARCH IN BUSINESS AND SOCIAL SCIENCES Vol. 10, No. 10, 2020, E-ISSN: 2222-6990 @ 2020 HRMARS

\section{Discussion}

The purpose of the study is to examine the relationship between love and marital satisfaction among the ethnic Chinese in Selangor. The findings show that love has a significant relationship with marital satisfaction. Love in this study which has been divided into three components namely, intimacy $(r=$ $\left.0.852^{* *}, p<0.00\right)$, passion $\left(r=0.835^{* *}, p<0.01\right)$ and commitment $\left(r=0.737^{* *}, p<0.01\right)$, showed a very high significant relationship with marital satisfaction. This study implements a survey study design using a questionnaire aimed at gathering personal background information and measuring samples' love and marital satisfaction.

A total of 384 ethnic Chinese samples who are Malaysian citizens, in the age group from 25 to 44 years old and have been married for at least one year voluntarily participated in this study. These findings show the importance of love in helping to increase marital satisfaction among married couples. The relationship between the three components in love is positive, so it can be interpreted that the higher the love, the higher the marital satisfaction. The findings of this study are parallel with the findings of studies conducted by Contreras and colleagues (1996); Muchtar (2004); Tang (2007); Syaidatun (2013); Carandang and Guda (2015); Hoesni, Kadir, Sulaiman and Hafidz (2016); Rohmah, Fitriana and Rahmatika (2017); Miri and Najafi (2017).

According to Dion and Dion (1996), the way individuals and groups view and conceptualise love and intimacy are different due to the influence of cultural differences. Based on observations, love is also influenced by cultural differences. Western society practices a culture of individualism and focuses on oneself. On the other hand, Malaysian society practices a culture of collectivism which is more concerned with family and togetherness (Razak, Hoesni, Zakaria, \& Ismail, 2015). Thus, researchers focus on specific cultures to understand love and marital satisfaction. Thus, based on this fact, it can be seen that various factors may be influenced by the social and cultural background which in turn, play an important role in improving the quality of marriage as well as expanding the scope of relationship in the field of marital satisfaction (Bradbury et al, 2000; Zakaria, Jaafar, Shafurdin, \& Hidayat, 2018; Hoesni \& Zakaria. 2019; Cai \& Zhang, 2020; Hoesni, Manap, \& Zakaria, 2020).

Nevertheless, there are still few studies conducted on the relationship between love and marital satisfaction among married ethnic Chinese. The samples that have been tested in this study are composed of a group of ethnic Chinese who are happily married, instead of those who are divorced and separated. By using the latter set of samples, we can predict the relationship between love and marital satisfaction in another environment so that this study can contribute towards enhancement and perform a preventive role. Overall, the findings show that love is predictable and it is one of the important factors in achieving marital satisfaction. Studies on various ethnicities can be actively implemented and are still very much needed in the future. In summary, the findings of the study are appropriate to the local context.

\section{Implications of the Study}

The findings of this study show that there is a relationship between love and marital satisfaction. Thus, this study enriches the field of psychology and serves as reference to the helping profession. In short, the component of love in this study has been found to be a basic reference in helping therapists and counsellors to address issues or to formulate interventions related to marital satisfaction. For example, the ability to develop therapeutically, especially to researchers and practitioners in the field of couple counselling and family therapy so that the source of "love" can be used in the therapeutic change process. Besides, this study shows that the study of love is still considered new in Malaysia. 
INTERNATIONAL JOURNAL OF ACADEMIC RESEARCH IN BUSINESS AND SOCIAL SCIENCES Vol. 10, No. 10, 2020, E-ISSN: 2222-6990 @ 2020 HRMARS

This study is still lacking in the involvement of multi-ethnic samples in Malaysia. From this study, the researchers hope to share the knowledge and information as well as benefitting the multicultural and multiethnic society in this country.

In addition, the findings of the study should be seen as a great opportunity for spouses and loving couples to focus their attention so they can complement each other in understanding themselves and as partners in love relationships. This knowledge is very important for them and their partners in the form of enlightenment or awareness. For example, they can participate in various psychoeducational programs and guidance on how to share knowledge in the ability to express love and to improve the quality of relationships in daily life. This can help individuals to prepare themselves to enter and manage the realm of marriage and strive to harmonise family life by achieving marital satisfaction.

\section{Conclusion}

In general, studies related to marital and family well-being are often debated by various parties. Some of the husbands and wives usually have the motivation and try to maintain a happy and peaceful marriage so they can avoid divorce. Therefore, to help improve the quality of relationships and the well-being of married couples, love is an important thing in achieving marital satisfaction.

At a glance, the findings of this study prove that the components of intimacy, passion and commitment play an important role in determining marital satisfaction. The results of Pearson correlation analysis show that there is a very high correlation between love and marital satisfaction among ethnic Chinese and this finding describes the importance of love in helping to increase marital satisfaction among married couples.

To conclude, the findings of this study are significant and reveal the knowledge that may serve as a reference to the helping profession in this country. In terms of implications, this study can enrich the field of psychology that focuses on marriage, culture and counselling. Couples who are already married or about to do so also need to equip themselves with sufficient knowledge of romance, marriage and family so they have the ability and the wisdom to build a prosperous and happy family. 


\section{APPENDIX}

\section{Demographics of Respondents (English Version)}

Gender:

a. Male

b. Female

Age: years old

Your hierarchy in the family:
a. The eldest
b. The youngest
c. In-between (please specify) number

Level of Education:

a. Did not complete primary school

b. Primary school

WORDS

c. SRP@PMR

d. SPM

e. STPM

f. Diploma

g. Bachelor's

h. Master's

i. Doctor of Philosophy (PhD)

(Career) Are you employed?

a. Yes

b. No

Parents' Marital Status:

a. Married and living together

b. Separated

c. Divorced

d. One of the parents has passed away

e. Others (please specify)

Length of Marriage: years

Total Number of Children (If any):

\section{Appreciation}


INTERNATIONAL JOURNAL OF ACADEMIC RESEARCH IN BUSINESS AND SOCIAL SCIENCES

Vol. 10, No. 10, 2020, E-ISSN: 2222-6990 @ 2020 HRMARS

The researcher would like to convey many thanks to Dr. Suzana Binti Mohd Hoesni, Prof. Madya Dr. Nor Ba'Yah Binti Abdul Kadir and Prof. Madya Dr. Zainah Binti Ahmad Zamani for the guidance and views they provided during the process of writing this article.

\section{References}

Abu Zahrin, S. A. (2013). Kefahaman Remaja Melayu Terhadap Konsep Cinta Dalam Islam

Dan Hubungannya Dengan Pemikiran Rasional Dan Akhlak Percintaan (2013). Doctoral Dissertation, Universiti Kebangsaan Malaysia, Bangi.

Adam, R. (2010). Hubungan Tingkah Laku Asertif Dengan Kepuasan Perkahwinan Dalam Kalangan Pasangan Dewasa Yang Berkahwin. Alat Ujian: DYADIC Adjustment Scale. Doctoral Dissertation. Universiti Kebangsaan Malaysia, Bangi.

Azahari, R. (2007). Permasalahan rumahtangga: Kajian di unit undang- undang keluarga jabatan agama islam daerah petaling, selangor. Jurnal Syariah, 15(1), 115-128.

Bowen, M. (1978). Family Therapy in Clinical Practice. New York: Jason Aronson.

Bradbury, T. N., Fincham, F. D., \& Beach, S. R. (2000). Research on the nature and determinants of marital satisfaction: A decade in review. Journal of Marriage And Family, 62(4), 964-980.

Cai, L., Wang, S., \& Zhang, Y. (2020). Vacation travel, marital satisfaction, and subjective wellbeing: a chinese perspective, Journal of China Tourism Research, 16(1), (2020), pp. 118-139.

Carandang, M. N. S., \& Guda, I. V. P. (2015). Indicators of marital satisfaction of batangueño couples: Components of love and the other external factors in marriage, International Journal of Information and Education Technology, 5(1), 60-67.

Contreras, R., Hendrick, S. S., \& Hendrick, C. (1996). Perspectives on Marital Love and Satisfaction in Mexican American and Anglo-American Couples. Journal of Counseling \& Development, 74(4), 408-415. doi:10.1002/j.1556-.

Demografi Cina Malaysia. (2019). Retrieved on $10^{\text {th }}$ December 2019 from https://ms.wikipedia.org/wiki/Demografi_Malaysia.

Dion, K. K., \& Dion, K. L. (1996). Cultural perspectives on romantic love. Personal Relationships, 3(1), 5-17. doi:10.1111/j.1475-6811.1996.tb00101.x.

Duvall, E. M., \& Miller, B. C. (1985). Marriage and Family Development (6th Ed.). New York: Harper \& Row Publishers, Inc.

Gana, K., Saada, Y., \& Untas, A. (2013). Effects of love styles on marital satisfaction in heterosexual couples: A dyadic approach. Marriage \& Family Review, 49(8), 754-772.

Gill, D. S., Christensen, A., \& Fincham, F. D. (1999). Predicting marital satisfaction from behavior: Do all roads really lead to Rome?. Personal Relationships, 6(3), 369-387.

Hameed, S. N. M. (2016). Peningkatan Cerai Runtuhkan Masyarakat. Utusan Malaysia. http://www.utusan.com.my/rencana/peningkatan-cerai-runtuhkan-masyarakat-1.200319.

Hellinger, B. (2014). Looking into the souls of children: the hellinger pedagogy in action, (2014). Hellinger Publications, Germany.

Hoesni, S. M., \& Zakaria. S. M. (2019). Marital Satisfaction and General Happiness among urban Malaysians in Klang Valley. International Journal of Recent Techology And Engineering. (8) https://www.ijrte.org/wpcontent/uploads/papers/v8i2S10/B10160982S1019.pdf.

Hoesni, S. M., Kadir, N. B. Y. A., Sulaiman, W. S. W., \& Hafidz, S. W. M. (2016). Love and marital satisfaction among urban malays: Comparing three groups Length of marriage". Jurnal Psikologi Malaysia, 30(2). 
INTERNATIONAL JOURNAL OF ACADEMIC RESEARCH IN BUSINESS AND SOCIAL SCIENCES Vol. 10, No. 10, 2020, E-ISSN: 2222-6990 @ 2020 HRMARS

Hoesni, S. M., Manap, J., \& Zakaria, S. M. (2020). Kebimbangan Berkomunikasi Dengan Pasangan Dan Kepuasan Perkahwinan Dalam Kalangan Individu Melayu yang Berkahwin di Lembah Klang, Malaysia Communication Apprehension with Spouse and Marital Satisfaction Among Married Urban Malay Individuals in Klang Valley, Malaysia)", Jurnal Psikologi Malaysia, 34(2).

Hoesni, S. M., Mohamad, M. S., Hafidz, S. W. M., Chong, S. T., \& Subhi, N. (2012). Meneroka konsep cinta dalam perkahwinan dalam kalangan Melayu bandar yang akan berkahwin", PERTANIKA Journal of Social Science and Humanities, 7(1), 76- 83.

Hong, L. F., \& Liu, S. J. (2013). The difference of culture in Malaysia: A comparison on marital circumstance between Chinese and Malay". Southeast Asian Affairs, 153(1), 62-72.

Imron, A. (2016). Memahami Konsep Perceraian dalam Hukum Keluarga. Buana Gender: Jurnal Studi Gender dan Anak, 1(1), 5-27.

Jawapan Parlimen Mengenai Statistik Kes Cerai Di Malaysia Mengikut Kaum. (2019). Retrieved on 2nd November 2009. Press Office, from http://teresakok.com/2009/11/03/jawapan-parlimenmengenai-statistik-penceraian-di-malaysia-mengikut-kaum-english-translation-below/.

Kes Cerai Tertinggi di Selangor. (2019). Retrieved on 17 September 2019 Kosmo Online, https://www.hmetro.com.my/mutakhir/2019/09/497752/kes-cerai-membimbangkan-diselangor.

Krejcie, V. R., \& Morgan, W. D. (1970). Determining Sampel Size for Research Activities, Educational and Psychological Measurement. 30, Duluth: University of Minnesota.

Markman, H. J., Rhoades, G. K., Stanley, S. M., Ragan, E. P., \& Whitton, S. W. (2010). The premarital communication roots of marital distress and divorce: the first five years of marriage. Journal of Family Psychology, 24(3), 289.

Miri, N., \& Najafi, M. (2017). The role of intimacy, loneliness, and Alexithymia in marital satisfaction prediction". Qom University Of Medical Sciences Journal, 11(3), 66-74.

Mohamad, N. (2012). Personaliti Narsisitik, Gaya Cinta Dan Kepuasan Cinta Sebagai Peramal Kecurangan". Masters Thesis. Universiti Kebangsaan Malaysia. Bangi.

Nelles, W. (2010). Men, Women And Love: About Childhood Claims And Adult Needs. Innenwelt Verlag Gmbh. German.

Nor, M. N. H. (2013). Cinta Dan Penghayatan Agama Terhadap Kepuasan Perkahwinan Individu Melayu Berkahwin. Alat Ujian: Triangular Theory Of Love Scales (TTLS), Comprehensive Measure of Islamic Religiosity (CMIR), Enrich Marital Satisfaction Scale, Doctoral Thesis. Universiti Kebangsaan Malaysia. Bangi.

Papalia, D. E., Olds, S. W., \& Feldman, R. D. (1998). Human development (7th ed.). Boston, Mass: McGraw Hill, New York.

Papalia, D. E., Olds, S. W., \& Feldman, R. D. (2009). Human development (11th ed.). Boston, McGraw Hill, New York.

Razak, S. N. F. A., Hoesni, S. M., Zakaria, E., \& Ismail, R. (2015). The Role of Dyadic Coping to Marital Quality-The Conceptual Paper. Procedia-Social and Behavioral Sciences", 211, 911-916.

Rohmah, Z. H., Fitriana, T. S., \& Rahmatika, R. (2017). Marital Quality in Early Years Marriage: The Role of Intimacy, Passion and Commitment. UI Proceedings on Social Science and Humanities,

Sahlan, M. (2012). Pengamatan Sosiologis Tentang Perceraian Di Aceh. Substantia, 14(1).

Schumm, W. A., Nichols, C. W., Schectman, K. L., \& Grigsby, C. C. (1986). The Kansas Marital Satisfaction Psychological Reports., 53, 567-572. 
INTERNATIONAL JOURNAL OF ACADEMIC RESEARCH IN BUSINESS AND SOCIAL SCIENCES Vol. 10, No. 10, 2020, E-ISSN: 2222-6990 @ 2020 HRMARS

See, T. L., \& Ismail, Z. (2018). Perkaitan Antara Gaya Bercinta dengan Kepuasan Perkahwinan dalam Kalangan Orang Islam di Selangor. EDUCATUM Journal of Social Sciences, 4(1), 22-31.

Sprecher, S., \& Hatfield, E. (2107). The importance of love as a basis of marriage: Revisiting Kephart (1967). Journal of Family Issues, 38(3), 312-335.

Sternberg, R. J. (1986). A Triangular theory of love. Psychological Review, 119- 135.

Sternberg, R. J. (1988). Triangulating love. In R. J. Sternberg, \& M.L. Barnes (Eds.), The psychology of love, New York, Yale University Press. 119- 138.

Sternberg, R. J., \& Weis, K. (2006). The new psychology of love. Yale University Press.

Tang, P. T. (2007). Romantic relationship: Love styles, triangular love and relationship satisfaction. City University of Hong Kong. Hong Kong.

Wade, E. P., \& Chai, C. Z. (2015). The psychology book: From shamanism to Cutting- Edge Neuroscience, 250 Milestones in the History of Psychology. Readingtimes, Taiwan.

Wallerstein, J. S., \& Lewis, J. M. (2004). The Unexpected Legacy of Divorce: Report of a 25-Year Study". Psychoanalytic psychology, 21(3), 353.

Weliangan, H. (2016). Hubungan triangular love dan kepuasan perkahwinan padan pasangan menikah 5-25 tahun", Doctoral Dissertation, Universitas Gunadarma, Jakarta.

Willi, J. (1997). The Significance of Romantic Love for Marriage. Family Process, 36(2), doi:10.1111/j.1545-5300.1997.00171.x. 171-182.

Zakaria, S. M., Jaafar, J. R., Shafurdin, N. S., \& Hidayat, N. D. (2018). Indikator Kualiti Perkahwinan Daripada Pelbagai Perspektif.

Zare, B. (2014). The relationship of personality traits and marital satisfaction. The probability of infidelity and risk of divorce. (Doctoral dissertation). Universiti Kebangsaan Malaysia. Bangi. 